\title{
First Five Years of JCIR: Note from the Editorial Committee of Journal of Clinical Interventional Radiology ISVIR (JCIR) and Indian Society of Vascular and Interventional Radiology (ISVIR) Leadership
}

\author{
Shyamkumar N. Keshava Sanjeeva Kalva² \\ ${ }^{1}$ Department of Interventional Radiology, Division of Clinical \\ Radiology, Christian Medical College, Vellore, Tamil Nadu, India \\ 2Division of Interventional Radiology, Department of Radiology, \\ Massachusetts General Hospital, Boston, Massachusetts, United \\ States \\ ${ }^{3}$ Department of Interventional Radiology, Sir Ganga Ram Hospital, \\ New Delhi, India \\ ${ }^{4}$ Department of Radiology, Sir HN Reliance Foundation Hospital, \\ Mumbai, Maharashtra, India
}

J Clin Interv Radiol ISVIR 2021;5:133-134.

During the annual conference of the Indian Society of Vascular and Interventional Radiology (ISVIR) in 2016, the leadership of the ISVIR conceptualized the need and benefit of an interventional radiology journal for the society. With the encouraging support from the members of the society, a dedicated team of members from the ISVIR leadership drafted the charter of the journal. The charter defined the principles of the journal, roles, and obligations of the editorial board, publisher contracts, financial support, and expectations to the members of the society. One important principle that society mandated was free access to journal contents for anyone across the world. The journal was named the "Journal of Clinical Interventional Radiology ISVIR (JCIR ISVIR)," the editorial team was selected, and Thieme Publishers was chosen as the publishers of the journal.

The editorial team was expanded quickly by incorporating associate editors, section editors, and eminent physicians across the continents as advisors to the journal. The editorial team worked tirelessly with the publishers in establishing processes for journal incorporation (International Standard Book Number [ISBN]), manuscript submission, reviewing/editing, and the design of the journal. The first copy of the journal was officially released at the 2017 ISVIR annual meeting. The journal became one of the most sought-after journals for manuscript submission among the Indian interventional radiologists. Given the open access and no-fee status of the journal, it attracted many

DOI https://doi.org/ $10.1055 / \mathrm{s}-0041-1736673$ ISSN 2457-0214

\begin{abstract}
Address for correspondence Shyamkumar N. Keshava, DMRD, DNB, FRCR, FRANZCR, Division of Clinical Radiology, Department of Interventional Radiology, Christian Medical College, Ida Scudder Road, Vellore 632004, Tamil Nadu, India (e-mail: shyamkumar.n.keshava@gmail.com).
\end{abstract}

international manuscripts. The initial apprehensions on the success of the journal faded quickly as the journal continued to receive high-quality manuscripts. We are very delighted to report that all the scheduled issues of JCIR were published on time. While the ISVIR committed to the financial needs of the journal, the quick and early recognition of the journal among the interventional radiologists across India has had an immediate effect on finance-generating advertisements in the journal.

Thieme Publishers played an important role in the success of the journal. In addition to the initial establishment of processes for journal submission/reviewing/editing, the Thieme team continuously worked with the editorial team to adapt to the challenges of coronavirus disease 2019 (COVID-19) pandemic. The executive director, Sunny Dasgupta was instrumental in marketing and getting indexation of the journal. The journal is now indexed in the Directory of Open Access Journals (DOAJ), Embase, EBSCO, ProQuest, and Scopus. ${ }^{1}$ An application has been submitted for PubMed Central indexing.

The strength of JCIR is its viewership; we take this opportunity to convey our heartfelt thanks to all the viewers. The backbone of JCIR is the contributors, readers, and fellow members of the society. The editorial team has spent countless hours in bringing the journal to this level. The ISVIR leadership has unanimously decided to extend the term of the present editorial team for another term. The ISVIR leadership 
134 Editorial

wishes strength and success to the editorial team. We echo the lines from the poem by Robert Frost: "But I have promises to keep, and miles to go before I sleep."

\section{Conflict of Interest}

None declared.

\section{Reference}

1 Journal of Clinical Interventional Radiology. https://en.wikipedia.org/wiki/Journal_of_Clinical_Interventional_Radiology. Accessed September 21, 2021 